\title{
ISOLASI DAN KERAGAMAN BAKTERI UREOLITIK LOKAL RIAU YANG BERPOTENSI SEBAGAI CAMPURAN BETON
}

\section{ISOLATION AND DIVERSITY OF LOCAL UREOLYTIC BACTERIA FROM RIAU THAT POTENTIALLY USE AS CONCRETE MIXTURE}

\author{
Mufidah Dwi Suci Ningsih, Tetty Marta Linda*, Bernadeta Leni Fibriarti \\ Program Studi Biologi, Fakultas Matematika dan Ilmu Pengetahuan Alam, Universitas Riau. \\ Kampus Bina Widya Km 12,5 Simpang Baru, Pekanbaru 28293 \\ *Corresponding author: tetty.martalinda@gmail.com
}

Naskah Diterima: 25 Juli 2017; Direvisi: 12 Agustus 2017; Disetujui: 7 November 2017

\begin{abstract}
Abstrak
Bakteri ureolitik merupakan mikroorganisme yang memiliki kemampuan untuk menghasilkan urease yang dapat mengendapkan kalsium karbonat (kalsit). Bakteri ini berpotensi sebagai agen bioremediasi logam berat dan sebagai bahan konstruksi beton. Penelitian ini bertujuan untuk mengisolasi, mengkarakterisasi, dan menguji presipitasi kalsit bakteri ureolitik dari tanah lokal Riau. Hasil penelitian memperoleh 30 isolat bakteri yang berhasil diisolasi dari tanah tempat pembuangan akhir, dan setelah dilakukan pewarnaan Gram, $77 \%$ isolat merupakan bakteri Gram positif dan hanya 33\% merupakan bakteri Gram negatif. Hasil uji presipitasi menunjukkan bahwa isolat- isolat dengan kode sp. 32, sp. 9, dan sp. 20 mampu membentuk kalsium karbonat berturutturut sebesar $0,129 \mathrm{~g}, 0,126 \mathrm{~g}$, dan $0,105 \mathrm{~g}$, setelah diinkubasi selama 7 hari pada medium cair yang diberi penambahan urea dan kalsium. Isolat-isolat bakteri tersebut memiliki hubungan kekerabatan yang dekat, yang ditandai dengan besarnya koefisien kekerabatannya, yaitu lebih dari $70 \%$. Dengan demikian, bakteri-bakteri yang terisolasi dan teruji dalam membentuk kalsium karbonat asal tanah lokal Riau berasal dari sekelompok bakteri, yang berpotensi untuk dikembangkan sebagai campuran beton.
\end{abstract}

Kata kunci: Bakteri ureolitik; Kalsium karbonat; Tanah; Urease

\begin{abstract}
Ureolytic bacteria are microorganisms that have the ability to produce urease that precipitates calcium carbonate (calcite). This bacteria has potential as an agent for bioremediation of heavy metal and as a concrete construction material. The aim of this research is concerning about isolation, characterization, and examination on calcite precipitate of the ureolytic bacteria from Riau local soil. The result showed that 30 isolates were isolated from landfill soil, and after Gram staining, 77\% of the isolates are Gram-positive and only 33\% are Gram-negative. The result of precipitation examination showed that the bacterial isolates sp. 32, sp. 9, and sp. 20 precipitated $0.129 \mathrm{~g}, 0.126 \mathrm{~g}$ and $0.105 \mathrm{~g}$ of calcium carbonate, respectively, after incubation for 7 days in broth medium added with urea and calcium. The bacterial isolates have a close relationship, which is characterized by the magnitude of the coefficient of more than $70 \%$. Therefore, the isolated and tested bacteria having the ability to form calcium carbonate from local soil Riau derived from a group of bacteria, which has a potential to be developed as a mixture of concrete.
\end{abstract}

Keywords: Calcium carbonate; Soil; Ureolytic bacteria; Urease

Permalink/DOI: http://dx.doi.org/10.15408/kauniyah.v11i1. 5737 


\section{PENDAHULUAN}

Bakteri adalah organisme prokariotik bersel tunggal dengan jumlah kelompok paling banyak dan dijumpai di tiap ekosistem terestrial. Walaupun ukurannya lebih kecil daripada aktinomisetes dan jamur, bakteri memiliki kemampuan metabolik lebih beragam dan memegang peranan penting dalam pembentukan tanah, dekomposisi bahan organik, remediasi tanah-tanah tercemar, transformasi unsur hara berintegrasi secara mutualistik dengan tanaman, dan juga sebagai penyebab penyakit tanaman (Saraswati et al., 2007).

Beberapa spesies bakteri berperan penting dalam proses presipitasi (pengendapan) mineral karbonat di banyak lingkungan alami, seperti tanah, formasi geologi, biofilm di air, yaitu dengan berperan sebagai agen geokimia dan menginduksi pembentukan mineral (Ghosh \& Mandal, 2006). Beberapa bakteri juga mampu mengendapkan kalsium karbonat (kalsit) dengan memproduksi enzim urease yang menghidrolisis urea (Siddique \& Chahal, 2011). Presipitasi kalsit ini dapat digunakan sebagai agen self-healing pada beton yang mengalami keretakan (Krishnapriya et al., 2015).

Self-healing concrete menggunakan kemampuan mikroba yang bertujuan untuk mengendapkan $\mathrm{CaCO}_{3}$ (kristal kalsit). Presipitasi kalsit yang terjadi akan menutupi keretakan yang terjadi pada beton, sehingga tidak mengurangi kekuatan beton tersebut. Beberapa bakteri yang dapat digunakan sebagai self-healing concrete yaitu sporosarcina pasteurii dan Pseudomonas aeruginosa yang berperan dalam pembentukan kalsit pada fase mortar semen (Achal et al., 2009). Berdasarkan penelitian Van et al. (2010), presipitasi kalsit yang diinduksi oleh Bacillus pasteurii dan Bacillus sphaericus dibuktikan efektif dalam mengatasi retak pada beton, Setelah dilakukan berbagai penelitian diketahui bahwa strain $B$. megaterium dan $B$. flexus juga memiliki kemampuan yang sama, yaitu mampu menghasilkan kalsit untuk menutupi keretakan pada beton (Krishnapriya et al., 2015).

Bakteri ureolitik mampu mengendapkan kalsium karbonat (kalsit) dengan memproduksi enzim urease, enzim ini menghidrolisis urease menjadi ammonia dan $\mathrm{CO}_{2}$, meningkatkan $\mathrm{pH}$ dan konsentrasi karbonat (Bharathi, 2012). Selanjutnya karbonat tersebut akan berikatan dengan ion seperti $\mathrm{Fe}^{3+}$ sebagai agen bioremediasi logam berat (Kang et al., 2015) dan $\mathrm{Ca}^{2+}$ untuk membentuk $\mathrm{CaCO}_{3}$ (kalsit) yang digunakan dalam mengatasi keretakan beton (Krishnapriya et al., 2015).

Berdasarkan hasil eksplorasi dari peneliti sebelumnya, bakteri ureolitik memiliki aktivitas enzim urease dan merupakan kelompok Bacillus Gram positif (Chahal et al., 2011) yang dapat diisolasi dari tanah kebun, tanah di sekitar pabrik semen (Krishnapriya et al.. 2015) dan tanah di tempat pembuangan akhir (Bharathi, 2012). Tempat Pembuangan Akhir (TPA) Muara Fajar merupakan tempat pembuangan akhir masyarakat Riau yang memiliki keberagaman jenis bakteri di dalamnya, yang salah satunya adalah bakteri ureolitik. Dalam upaya memperoleh bakteri ureolitik, penelitian ini dilakukan dengan tujuan untuk mengisolasi, mengkarakterisasi dan menguji presipitasi kalsit bakteri ureolitik dari tanah lokal Riau.

\section{MATERIAL DAN METODE}

Penelitian ini dilakukan di Laboratorium Mikrobiologi, Jurusan Biologi Fakultas Matematika dan Ilmu Pengetahuan Alam Universitas Riau. Sampel tanah diambil dari dua stasiun (Stasiun 1: N 00³8,738' E $101^{\circ} 26,565^{\prime}$ dan Stasiun 2: N 00³8,731' E 101 $\left.{ }^{\circ} 26,553^{\prime}\right)$ di TPA Muara Fajar Rumbai Pekanbaru. Setiap stasiun diambil lima titik sampel yang selanjutnya dikompositkan, dimasukkan ke dalam plastik, lalu dimasukkan ke dalam cooler box selama dibawa ke laboratorium.

\section{Isolasi Kandidat Bakteri Ureolitik Penghasil Spora}

Sebanyak $10 \mathrm{~g}$ tanah diambil dan dimasukkan ke dalam labu Erlenmeyer yang berisi $90 \mathrm{~mL} \mathrm{NaCl}$ untuk selanjutnya dilakukan pemanasan pada waterbath dengan suhu $80{ }^{\circ} \mathrm{C}$ selama 15 menit. Setelah dingin, $1 \mathrm{~mL}$ sampel dimasukkan ke dalam $9 \mathrm{~mL}$ larutan garam fisiologis $(0,85 \%)$ dan dilakukan pengenceran hingga $10^{-5}$. Sebanyak $1 \mathrm{~mL}$ pada pengenceran $10^{-2}, 10^{-3}, 10^{-4}$ dan $10^{-5}$ diambil lalu ditumbuh- 
kan secara pour plate pada medium NA dan diinkubasi selama 1x24 jam pada suhu ruang. Isolat bakteri yang tumbuh dilakukan pemurnian dengan teknik streak kuadran, selanjutnya dipindahkan pada agar miring sebagai kultur stok dan disimpan pada suhu $4{ }^{\circ} \mathrm{C}$.

\section{Karakterisasi Morfologi Dan Fisiologi}

Seluruh bakteri yang berhasil diisolasi dilakukan karakterisasi yang mengacu pada Prescott (2002), yang meliputi ukuran koloni (kecil, sedang, besar), bentuk koloni (filamentous, circular, irregular, rhizoid), tepian koloni (serrate, entire, lobate, undulate), elevasi koloni (flat, raised convex), pertumbuhan pada agar tegak (filiform, papiliate, beaded, villose, echinulate), pertumbuhan pada agar miring (sedang, lebat, echinulate, effuse, spreading, rhizoid, filiform, beaded), pertumbuhan pada medium cair (pellicle, sediment, uniform turbidity), bentuk sel (coccus, streptobacil, streptococcus, bacil rounded end), pewarnaan Gram (Gram positif dan negatif), uji katalase, reduksi methylene blue, uji hidrolisis pati (1\%), pertumbuhan pada variasi suhu $45{ }^{\circ} \mathrm{C}$ dan $50{ }^{\circ} \mathrm{C}$ (tinggi, sedang, rendah, tidak tumbuh). Data yang diperoleh dianalisis menggunakan program NTSYS 2.02.

\section{Uji Aktivitas Urease}

Sebanyak $5 \mathrm{~g} \mathrm{NaCl}, 1 \mathrm{~g}$ pepton, $1 \mathrm{~g}$ glukosa, $2 \mathrm{~g} \mathrm{KH}_{2} \mathrm{PO}_{4}, 0,012 \mathrm{~g}$ phenol red dan $15 \mathrm{~g}$ agar dilarutkan dalam $900 \mathrm{~mL}$ akuades dan dilakukan sterilisasi pada autoklaf selama 15 menit pada suhu $121^{\circ} \mathrm{C}$ dengan tekanan 15 psi. Selanjutnya dilakukan penambahan $20 \mathrm{~g}$ urea dalam $100 \mathrm{~mL}$ akuades yang telah disterilisasi menggunakan filter. Medium dituang ke dalam tabung reaksi steril dan dimiringkan hingga medium memadat. Isolat bakteri yang merupakan Gram positif selanjutnya distreak di atas permukaan medium dan diinkubasi pada suhu $30{ }^{\circ} \mathrm{C}$ selama 4 hari. Hasil positif ditandai dengan perubahan warna dari kuning menjadi merah pekat (deep pink) pada medium (Hammad et al., 2013).

\section{Uji Presipitasi $\mathrm{CaCO}_{3}$ (Kalsit)}

Uji presipitasi dilakukan menggunakan medium dengan komposisi nutrient broth $3 \mathrm{~g}$, urea $20 \mathrm{~g}$ dan $\mathrm{CaCl}_{2} .2 \mathrm{H}_{2} \mathrm{O} 28,5 \mathrm{~g}$ dilarutkan ke dalam $1000 \mathrm{~mL}$ akuades. Tiga isolat bakteri masing-masing dipersiapkan inokulum dengan total populasi $10^{5} \mathrm{CFU} / \mathrm{mL}$ pada medium NB$\mathrm{U} / \mathrm{Ca}$. Satu $\mathrm{mL}$ inokulum ditambahkan ke dalam $9 \mathrm{~mL}$ larutan garam fisiologis $(0,85 \%)$ dan dilakukan pengenceran bertingkat serta Total Plate Count (TPC) untuk mendapatkan populasi $10^{5} \mathrm{CFU} / \mathrm{mL}$. Sebanyak $0,6 \mathrm{~mL}$ inokulum diinokulasikan kedalam $30 \mathrm{~mL}$ medium NB-U/Ca dan diinkubasi di atas shaker (130 rpm) pada suhu $30{ }^{\circ} \mathrm{C}$ selama 7 hari. Presipitat $\mathrm{CaCO}_{3}$ disaring menggunakan kertas saring (Whatman No. 42) yang sebelumnya telah dikeringkan di dalam oven pada suhu $60{ }^{\circ} \mathrm{C}$ selama 3 jam lalu ditimbang. Berat presipitat $\mathrm{CaCO}_{3}(\mathrm{Wc})$ merupakan selisih antara berat kertas saring dan presipitat (Wfc) dikurangi berat kertas saring (Wf) (Krishnapriya et al., 2015).

\section{Analisis Data}

Hasil karakter makroskopis dan mikroskopis dianalisa secara deskriptif dan diolah menggunakan program NTSYS 2.02, sedangkan uji presipitasi kalsium karbonat dilakukan secara kuantitatif.

\section{HASIL}

TPA Muara Fajar Rumbai merupakan lokasi tempat penimbunan sampah yang diperoleh dari seluruh masyarakat di Kota Pekanbaru. Timbunan sampah umumnya terdiri dari sampah organik dan anorganik. Tanah pada lokasi ini memiliki pH 6,9. Hasil isolasi bakteri di tanah TPA, ditemukan 30 isolat bakteri yang selanjutnya diberi nama spesies 1 (sp. 1), spesies 2 (sp. 2) dan seterusnya. Beberapa karakteristik morfologi dan fisiologi dari masing-masing isolat bakteri dapat dilihat pada Tabel 1. Berdasarkan karakterisasi parsial yang telah dilakukan, selanjutnya dilakukan pembuatan pohon kekerabatan menggunakan program NTSYS 2.02 dan diperoleh hasil seperti pada Gambar 1.

Total $77 \%$ isolat merupakan bakteri Gram positif dan hanya $23 \%$ yang merupakan bakteri Gram negatif. Bakteri Gram positif diuji kemampuannya dalam menghasilkan enzim urease menggunakan medium Christensen's Urea Agar dan dikatakan positif jika terjadi perubahan warna medium dari berwarna kuning menjadi merah pekat (deep 
pink) (Gambar 2). Selanjutnya tiga isolat bakteri diuji presipitasi kalsit dan didapatkan hasil kalsit pada sp. 9, sp. 20, dan sp. 32 mampu mengendapkan kalsit berturut-turut sebesar 0,126, 0,105, dan 0,129 g (Gambar 3). Kehadiran kalsit ditandai dengan adanya butiran berwarna putih di bagian bawah medium uji (Gambar 4).

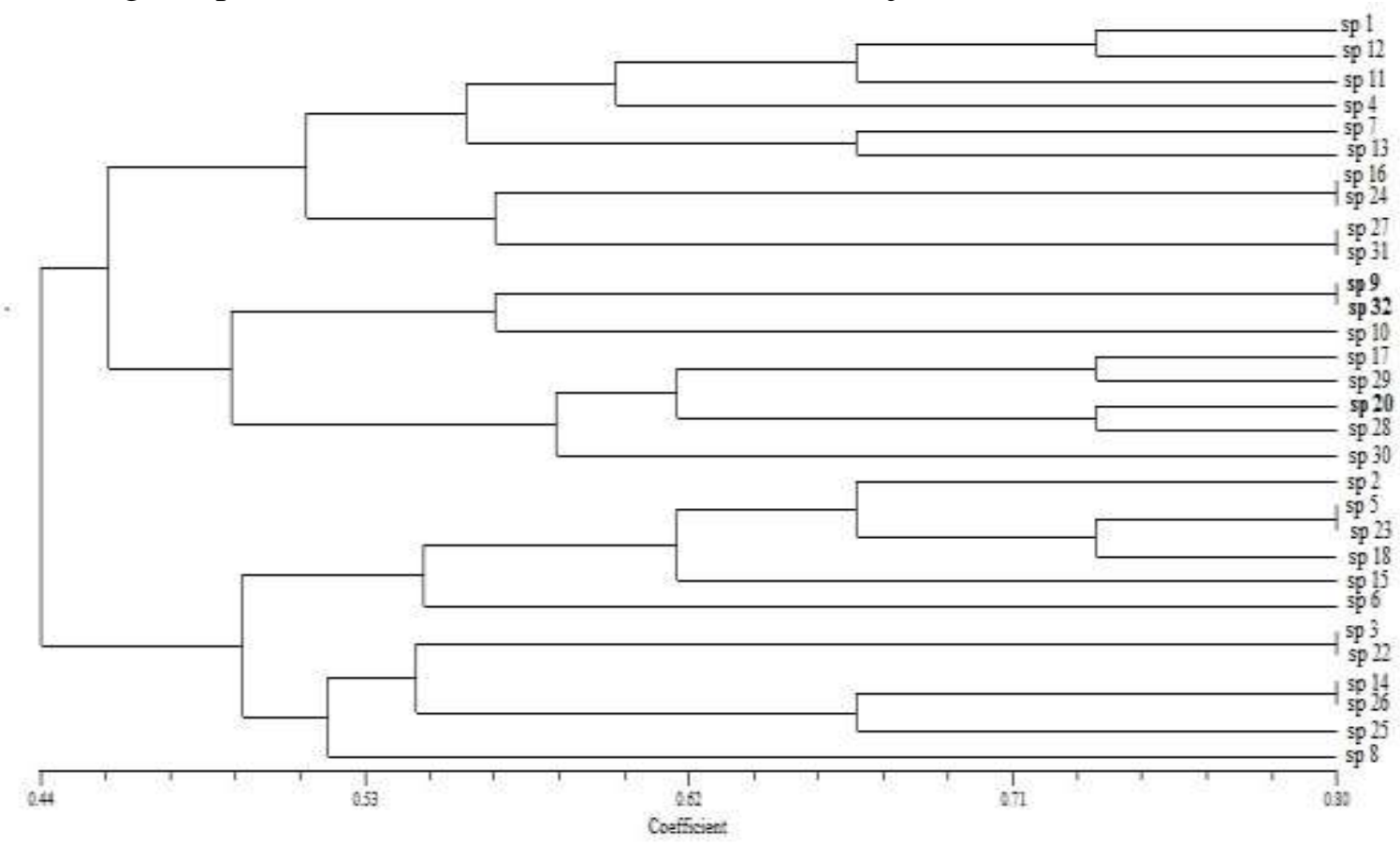

Gambar 1. Pohon kekerabatan tiap isolat bakteri yang berhasil diisolasi Tempat Pembuangan Akhir (TPA) Muara Fajar Rumbai Pekanbaru

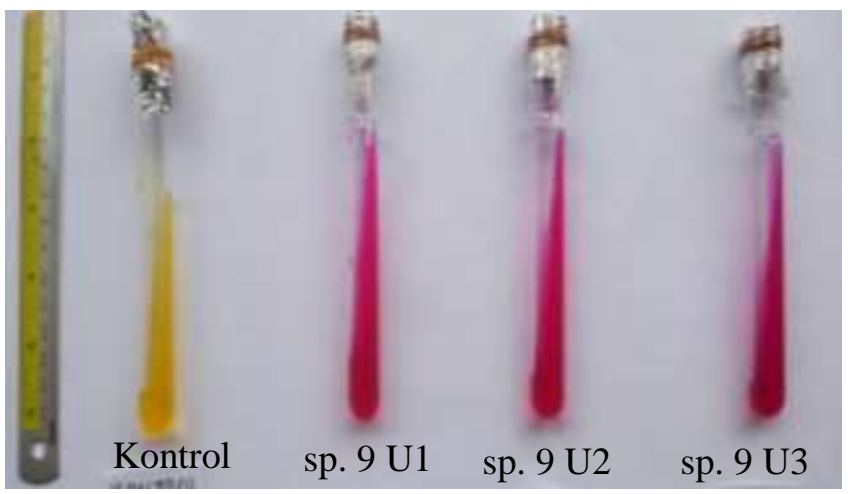

Gambar 2. Uji urease isolat sp. 9 menggunakan medium Christensen's Urea Agar waktu inkubasi 72 jam pada suhu $30^{\circ} \mathrm{C}$ dengan tiga ulangan

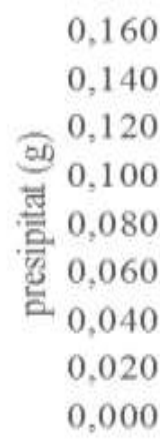

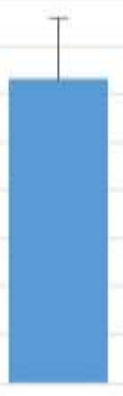

Sp 9

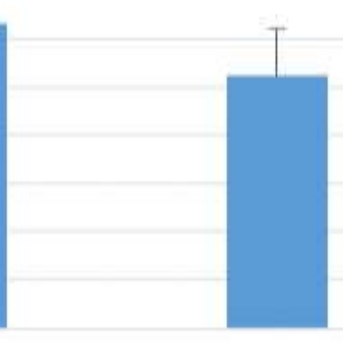

Sp 20

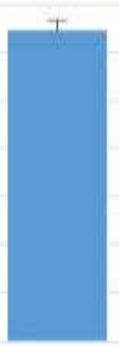

Sp 32

isolat bakteri

Gambar 3. Berat presipitat kalsium karbonat yang dihasilkan pada waktu inkubasi selama 7 hari pada suhu $30^{\circ} \mathrm{C}$ dan kecepatan $130 \mathrm{rpm}$ 

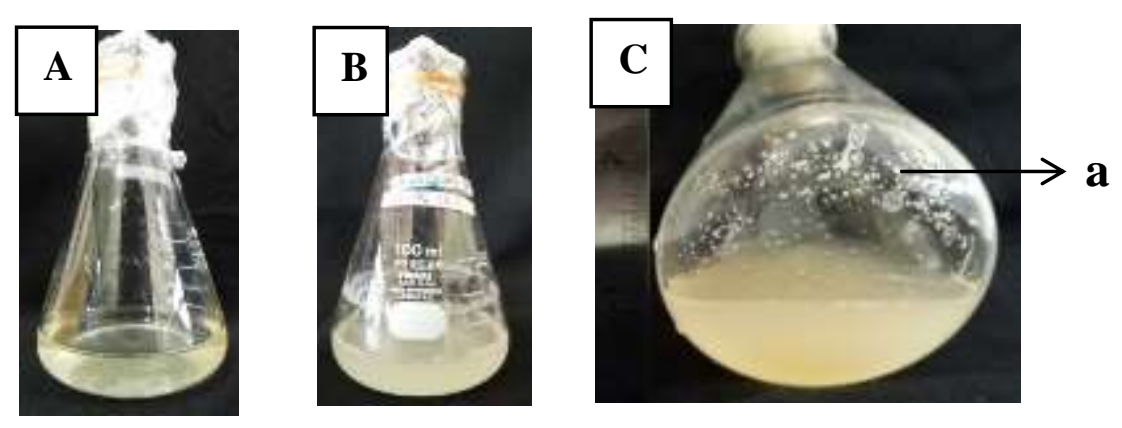

Gambar 4. Uji presipitasi kalsium karbonat menggunakan medium NB-U/Ca pada suhu $30{ }^{\circ} \mathrm{C}$ kecepatan 130 rpm selama 7 hari: (A) kontrol, (B) isolat sp. 32, (C) presipitasi kalsium karbonat oleh bakteri. Keterangan: a. presipitasi kalsium karbonat (kalsit)

\section{PEMBAHASAN}

\section{Isolasi Bakteri Ureolitik dan Karakterisasi} Parsial

Tiga puluh isolat bakteri yang berhasil diisolasi kemudian diremajakan dan diuji jenisnya. Sebanyak $77 \%$ isolat, yaitu sp. 1, sp. 4, sp. 5, sp. 6, sp. 7, sp. 8, sp. 9, sp. 10, sp. 11, sp. 12 , sp. 13 , sp. 15 , sp. 16, sp. 17, sp. 18, sp. 20, sp. 23 , sp. 27 , sp. 28 , sp. 29 , sp. 30 , sp. 31 , sp. 32, merupakan Gram positif, sedangkan 23\% merupakan Gram negatif. Adapun bakteri Gram positif kelompok Bacillus merupakan bakteri yang umum diketahui sebagai penghasil urease. Bakteri Gram positif ditandai dengan warna ungu setelah dilakukan pewarnaan Gram. Hadioetomo (1985) menyatakan bahwa dinding sel bakteri Gram positif memiliki lapisan peptidoglikan yang tebal, yang pada saat perlakuan alkohol terjadi dehidrasi yang meyebabkan pori-pori dinding sel menutup, sehingga mencegah larutnya kompleks kristal violet-iodin dan tetap berwarna ungu hingga akhir. Sementara itu, bakteri Gram negatif memiliki lapisan lipid yang tebal dan terlarut saat perlakuan alkohol dan kompleks kristal violet-iodin merusaknya, sehingga memperbesar pori-pori dinding sel dan menyebabkan warna merah muda dari safranin pada akhir pewarnaan.

Karakterisasi parsial dilakukan untuk mengetahui tingkat kekerabatan dari ketigapuluh isolat bakteri. Pada pohon kekerabatan (Gambar 1) terdapat dua cabang besar yang memisahkan isolat-isolat bakteri. Adapun cabang pertama umumnya merupakan bakteri Gram positif dan cabang kedua merupakan bakteri Gram negatif. Isolat yang merupakan bakteri ureolitik memiliki hubungan yang dekat ditandai dengan koefisien $>70 \%$. Isolat sp. 9 dan sp. 32 memiliki hubungan kekerabatan yang sangat dekat ditandai dengan koefisien sebesar $80 \%$ dan kekerabatan terendah pada isolat sp. 28 terhadap sp. 2 dengan koefisien $20 \%$.

Selanjutnya seluruh isolat yang merupakan Gram positif diuji kemampuannya dalam menghasilkan enzim urease. Kemampuan bakteri dalam menghasilkan enzim urease dapat dilihat dengan menumbuhkan bakteri pada medium Christensen's agar (Hammad et al., 2013). Kehadiran enzim urease akan menyebabkan terjadinya perubahan warna medium dari warna kuning menjadi merah pekat (deep pink) (Gambar 2). Adanya perubahan warna yang tejadi pada medium dikarenakan medium berisi phenol red sebagai indikator perubahan $\mathrm{pH}$. Ketika bakteri menghidrolisis urea pada medium menggunakan enzim urease, medium yang semula berwarna kuning akan berubah menjadi warna merah pekat. Urease merupakan enzim yang diperlukan untuk menghidrolisis urea menjadi ammonia dan $\mathrm{CO}_{2}$, meningkatkan $\mathrm{pH}$ dan konsentrasi karbonat di lingkungan bakteri (Bharathi, 2012). Pada bakteri yang mampu menghidrolisis urea, enzim urease mengkatalisis substrat urea dan mengendapkan ion karbonat ketika ada ammonium. Ion karbonat ini ketika terdapat sumber kalsium akan mempresipitasi $\mathrm{CaCO}_{3}$ yang dibutuhkan dalam banyak bidang, yang salah satunya berfungsi sebagai penutupan retak pada beton.

\section{Uji Presipitasi Kalsium Karbonat}

Karbonat atau bikarbonat dihasilkan dari hidrolisis urea oleh enzim urease pada bakteri. 
Dikatalisis dengan cara urease, urea terdegradasi menjadi karbonat dan amonium, dan akibatnya meningkatkan nilai $\mathrm{pH}$, serta konsentrasi karbonat di lingkungan bakteri. Satu mol urea dihidrolisis secara intraselular sampai 1 mol amonia dan 1 mol karbonat (Persamaan 1), yang secara spontan menghidrolisis menjadi $1 \mathrm{~mol}$ amonia dan asam karbonat (Persamaan.2) dan kemudian mencapai keseimbangan dalam air untuk membentuk bikarbonat dan 2 mol amonium dan ion hidroksida (Persamaan 3 dan 4) (De Muynck et al., 2010).

$$
\begin{aligned}
& \mathrm{CO}\left(\mathrm{NH}_{2}\right)_{2}+\mathrm{H}_{2} \mathrm{O} \rightarrow \mathrm{H}_{2} \mathrm{COOH}+\mathrm{NH}_{3} \text { (1) } \\
& \mathrm{NH}_{2} \mathrm{COOH}+\mathrm{H}_{2} \mathrm{O} \rightarrow \mathrm{NH}_{3}+\mathrm{H}_{2} \mathrm{CO}_{3} \\
& 2 \mathrm{NH}_{3}+2 \mathrm{H}_{2} \mathrm{O} \rightarrow 2 \mathrm{NH}_{4}^{+}+2 \mathrm{OH}^{-} \\
& 2 \mathrm{OH}^{-}+\mathrm{H}_{2} \mathrm{CO}_{3} \rightarrow \mathrm{CO}_{3}{ }^{2-}+2 \mathrm{H}_{2} \mathrm{O} \\
& \mathrm{Ca}^{2+}+\mathrm{Cell}^{2} \rightarrow \mathrm{Cell}^{2-} \mathrm{Ca}^{2+} \\
& \mathrm{Cell}_{-} \mathrm{Ca}^{2}++\mathrm{CO}_{3}{ }^{2-} \rightarrow \mathrm{CaCO}_{3}
\end{aligned}
$$

Kehadiran ion kalsium dalam sistem akan menyebabkan pengendapan kalsium karbonat ketika tingkat jenuh tertentu tercapai. Mekanisme presipitasi kalsium karbonat disebabkan oleh aktivitas enzim urease. Ion kalsium dalam larutan akan tertarik ke dinding sel mikroorganisme karena bermuatan negative (Persamaan 5) (De Muynck et al., 2010). Setelah penambahan urea ke sistem, mikroorganisme mengubah urea menjadi karbon anorganik terlarut (Dissolved Inorganic Carbon (DIC)) dan ammonium (AMM) yang dikeluarkan ke lingkungan. Kehadiran ion kalsium menyebabkan kondisi jenuh dan pengendapan kalsium karbonat pada dinding sel mikroorganisme. Setelah beberapa saat, seluruh sel menjadi terselubungi oleh endapan kalsium karbonat (Hammes \& Verstreate, 2002). Adapun endapan kalsium karbonat akan berwarna putih dan berada di bagian bawah medium pada uji presipitasi $\mathrm{CaCO}_{3}$ menggunakan medium NB-U/Ca (Gambar 4).

Dari 30 isolat yang berhasil diisolasi, 3 isolat, yaitu sp. 9, sp. 20 dan sp. 32, menunjukkan hasil positif enzim urease setelah diuji kemampuannya dalam mengendapkan kalsium karbonat. Pada Gambar 3 dapat diketahui bahwa sp. 32 memiliki aktivitas tertinggi dalam membentuk $\mathrm{CaCO}_{3}$, yaitu sebesar $0,129 \mathrm{~g}$, pada waktu inkubasi 7 hari; selanjutnya diikuti oleh sp. 9 sebanyak $0,126 \mathrm{~g}$ dan sp. 20 sebanyak 0,105 g. Hasil pada penelitian ini lebih rendah dibandingkan penelitian Krishnapriya et al. (2015) yang mengisolasi bakteri ureolitik dari tanah di sekitar pabrik semen yang mampu mengendapkan kalsium karbonat, yaitu $B$. megaterium BSKAU, $B$. licheniformis BSKNAU dan $B$. flexus BSKNAU, yang berturut-turut menghasilkan kalsit sebesar 0,84, 0,82 dan 0,76 g. Selain itu, ketiga isolat ini mampu meningkatkan kekuatan dan menutupi keretakan beton dengan mencampurkannya langsung ke dalam campuran beton, sehingga beton dengan campuran bakteri tersebut mampu meningkatkan kekuatan beton. Beton kontrol hanya memiliki kuat tekan 33,00 MPa, sedangkan beton campuran bakteri $B$. megaterium memiliki kuat tekan hingga 38,30 $\mathrm{MPa}$.

Adanya perbedaan berat presipitat yang terjadi disebabkan karena setiap jenis bakteri memiliki kemampuan yang berbeda-beda dalam menghasilkan enzim urease, dan tentunya akan mempengaruhi jumlah kalsium karbonat yang akan terbentuk (Henriques, 2011 dalam Alhour, 2013). Ketiga isolat bakteri, yaitu sp. 9, sp. 20 dan sp. 32, diduga merupakan kelompok bakteri Bacillus sp. dan dapat dikembangkan sebagai bahan konstruksi beton.

\section{SIMPULAN}

Berdasarkan hasil penelitian, dapat disimpulkan bahwa dari ke-30 isolat bakteri yang berhasil diisolasi, isolat sp. 9, sp. 20 dan sp. 32 merupakan bakteri ureolitik yang mampu menghasilkan kalsium karbonat, dan memiliki hubungan kekerabatan yang dekat, yang ditandai dengan besarnya koefisien kekerabatannya, yaitu $>70 \%$.

\section{SARAN}

Perlu dilakukan penelitian lebih lanjut dalam pengoptimuman variasi jumlah inokulum yang digunakan pada penelitian lanjutan, sehingga dapat menghasilkan berat presipitat kalsit yang lebih besar, serta aplikasi bakteri langsung pada campuran beton

\section{UCAPAN TERIMAKASIH}

Terimakasih kepada KEMENRISTEK DIKTI melalui Program Kreativitas 
Mahasiswa Penelitian (PKM-PE) Tahun 2017 yang telah mendanai penelitian ini atas nama Mufidah Dwi Suci Ningsih dibawah bimbingan Ibu Dr. Tetty Marta Linda, M.Si.

\section{REFERENSI}

Achal, V., Mukherjee, A., Basu, P. C., \& Reddy, M. S. (2009). Strain improvement of Sporosarcina pasteurii for enhanced urease and calcite production. Journal of Industrial Microbiology \& Biotechnology, 36(7), 981-988.

Alhour, M. T. (2013). Isolation, characterization and application of calcite producing bacteria from urea rich soils (Master's thesis). Science in Biotechnology, Islamic University of Gaza.

Bharathi, N. (2012). Calcium carbonate precipitation with growth profile of isolated ureolytic strains. International Journal of Science and Research, 3(9), 2045-2049.

Chahal, N., Rajor, A., \& Siddique, R. (2011). Calcium carbonate precipitation by different bacterial strains. African Journal of Biotechnology, 10(42), 83598372.

De Muynck, W., Belie, D. N., \& Verstraete, W. (2010). Microbial carbonate precipitation in construction materials: a review. Ecological Engineering, 36(2), 118-136.

Ghosh, P., \& Mandal, S. (2006). Development of bioconcrete material using an enrichment culture of novel thermophilic anaerobic bacteria. Indian Journal of Experimental Biology, 44(4), 336-339.

Hadioetomo, R. S. (1993). Mikrobiologi dasar dalam praktek. teknik dan prosedur dasar laboratorium. Jakarta: PT Gramedia.

Hammad, I. A., Talkhan, F. N.,\& Zoheir, A. E. (2013). Urease activity and introduction of calcium carbonate precipitation by Sporosarcina pasteurii NCIMB 8841. Journal of Applied Sciences Research, 9(3), 1525-1533.

Hammes, F., \& Verstraete, W. (2002). Key roles of $\mathrm{pH}$ and calcium metabolism in microbial carbonate precipitation. Reviews in Environmental Science and Biotechnology, 1(1), 3-7.

Kang, C. H., Oh, S. J., Han, S. H., \& Nam, I. H. (2015). Bioremediation of lead by ureolytic bacteria isolated from soil at abandoned metal mines in South Korea. Ecological Engineering, 74, 402-407.

Krishnapriya, S., Babu, D. L. V., \& Arulraj, G. P. (2015). Isolation and identification of bacteria to improve the strenght of concrete. Microbiological Research, 174, 48-55.

Prescott, H. (2002). Laboratory exercise in microbiology. The McGraw-Hill Companies.

Saraswati, R., Husen, E., \& Simanungkalit, R. D. M. (2007). Metode analisis biologi tanah. Bogor: Balai Besar Penelitian dan Pengembangan Sumberdaya Lahan Pertanian.

Van Tittelboom, K., De Belie, N., De Muynck, W., \& Verstraete, W. (2010). Use of bacteria to repair cracks in concrete. Cement and Concrete Research, 40(1), 157-66. 